\section{STEM professionals utilize established routes of science advocacy in United States}

$\mathrm{T}^{\mathrm{h}}$ he seemingly rapid politicization of science within the US Congress and the Trump administration's significant changes and proposed deep budget cuts across the science agencies (see MRS Bulletin, August 2017) have jolted many science, technology, engineering, and mathematics (STEM) professionals off the sidelines and onto the frontlines of science advocacy. Many have joined grassroots movements such as the March for Science (see MRS Bulletin, July 2017), and the number of scientists participating in established advocacy efforts in the United States has steadily been on the rise.

A number of scientific societies and institutions have long played an active role in science advocacy. "Through consistent and insistent contact, you lay the groundwork to be the first to come to mind when a relevant issue comes up," says Damon Dozier, Government Affairs Director of MRS. This has led to the building of relationships with policymakers as well as the establishment of a number of different advocacy methods that are now readily available to STEM professionals.

Through an effort called Materials Voice, MRS developed a method that allows its US-based members to find contact information for their elected officials as well as use an online platform to directly write to their legislators. In addition, the Grassroots Subcommittee of the MRS Government Affairs Committee (GAC) follows current issues that impact the materials community and drafts letters that address these issues. At each MRS Meeting, GAC hosts a booth where members can sign and send these letters on key issues and/or draft and send their own letters.

At the recent 2017 MRS Spring Meeting held in Phoenix, Ariz., 1025 letters were sent from members to their elected representatives. These letters addressed two current issues - sustained funding for scientific research and long-term support for federal energy and manufacturing programs. "I am a strong proponent for our letter-writing campaigns because it is perhaps the most impactful way that we can bundle collective sentiment among our membership on important $R \& D$ [research and development] and materials issues and deliver a cohesive message to elected offcials as concerned citizens and constituents," says Brent Carey, chair of the MRS Grassroots Subcommittee.

The letters were especially timely because they reached legislators' offices during the period when Congress was working on appropriations legislation for the remainder of 2017. The president's proposed budget would have scaled back significant funding for most of the federal science agencies, but the omnibus Appropriations bill enacted by Congress included an overall increase $(\sim 5 \%)$ in these budgets.

A second well-established avenue of advocacy is meeting with legislators or their staff members. With advanced notice, most congressional offices will schedule a meeting with their constituents or work to accommodate drop-in meetings as staffing allows. Many scientific societies and institutions have also established Congressional Visits Days (CVD), where members can schedule meetings with their elected officials to discuss the importance of science in their lives and the impacts that they see in their local districts and states.

Bill Hammetter, the chair of the MRS CVD Subcommittee, says that he initially attended CVD because he believes that "science does not speak for itself."

The latest MRS CVD was held in May 2017 and participants focused on the importance of strong support for continued federal research funding in fiscal year 2018. Howard Katz, professor of materials science and engineering at Johns Hopkins University, has frequently participated in CVD over the years but says he feels "a much greater sense of urgency now about educating legislators who may not sufficiently appreciate the value of science and technology to their districts and the nation as a whole, and to provide resources to those legislators who are already appreciative so they can help educate their colleagues."

Laura Lewis, Cabot Professor at Northeastern University, agrees with Katz, saying, "I could not think of a more important time to participate in this activity." Lewis adds, "The most important message we tried to share was that materials underlie everything - there is no advanced society without materials, and the answers to all the important societal questions in some way involve materials."

Often, the more tailored and personal the message is, the more impact it will have in an office. David Larbalestier, Francis Eppes Professor at Florida State University, says it is important to remember "the locality of politics and the importance, especially, of lobbying your local representatives with your concerns."

Kevin Jones, distinguished professor of materials science and engineering at the University of Florida, gives an example of using a message tailored to his district saying that he spoke about how many of the federally funded basic science agencies "recognize the need for global thinking engineers and for educating the general population on the role of science and engineering in society," which led to the creation of a class at the University of Florida on the impact of materials on society (see MRS Bulletin, August 2017). "The legislators were surprised that supporting basic research funding could have such positive effects on improving the social literacy of future scientists and engineers as well as improving the technical literacy of non-engineers," Jones says.

A third established route of advocacy is through serving in a fellowship position either on Capitol Hill or in the executive branch offices. Fellowships typically take the form of a one-year assignment, and while each fellowship has different qualification requirements, many opportunities are available for STEM professionals from every career stage. For some fellows, the fellowship is a sabbatical with opportunities to learn about the interface between 
science and government; for others, the fellowship is the first step into a new career in science policy and advocacy.

Two fellowship programs, the Jefferson Science Fellowship Program and the Franklin Fellows Program, are geared toward mid- to senior-level professionals who are US citizens. The Jefferson Fellowship is open only to tenured (or similarly ranked) faculty at US institutions of higher education, while Franklin Fellows may come from a range of backgrounds including academia, the private sector, and nongovernmental organizations. Both Jefferson Fellows and Franklin Fellows spend a year serving as science advisors at the US Department of State or US Agency for International Development (USAID).

The application period for the Jefferson Fellowship is open and will close at the end of October. The Franklin Fellows Program announces vacancies via USAJOBS.

Although it is sometimes difficult for mid- and senior-level professionals to take a year away from their career and serve as a science advocate, former fellows overwhelmingly recommend the programs. Alan Hurd, executive advisor at Los Alamos National Laboratory and a former Franklin Fellow, says, "My service at State was very rewarding, and I have never met anyone who felt that a DC advisor position was a waste of time."

Additional one-year fellowship opportunities are available for STEM professionals in both the legislative and executive branches, and are open to the range of career stages and backgrounds.

Legislative branch fellowships, better known as Congressional Fellowships, are sponsored by a broad range of scientific and professional societies. Congressional Fellows spend their fellowship year in the offices of members of Congress or Congressional Committees acting as staff members, covering a range of science- and nonscience related issues. MRS co-sponsors two Congressional Fellowships with partner societies The Minerals, Metals and Materials Society (TMS) and The Optical Society (OSA); the application for the 2018 term is open and closes on January 5, 2018.

"The program goal [of the Congressional Fellowship] is to ensure scientific expertise and input into the policymaking process," says Kevin Whittlesey, chair of the GAC and 2006-2007 MRS/OSA Congressional Fellow. Former fellows (see November 2015 MRS Bulletin) have chosen a range of career options including remaining in legislative offices, returning to academia, transitioning into the private sector, and pursuing other opportunities in Washington, DC, at govern-

ment agencies or within the variety of government-related industries. According to Whittlesey, regardless of the path former fellows pursue, they embark upon their new roles "with a better understanding of the relationship between science and policymaking, and how they might be able to play a role in it."

Executive branch fellowships are administered by the American Association for the Advancement of Science (AAAS) and fellows are placed in a range of federal agencies. Commonly known as AAAS Fellowships, the hosting agencies fund them and fellows serve alongside staff members working in a broad range of policy areas. Specific areas of interest to materials researchers include big data and analytics, education, energy, environment, security, and health. Applications for the AAAS Fellowships are open and close on November 1, 2017.

"I applied to the MRS/OSA Congressional Fellowship in 2010 with the expectation that the fellowship could be the start of a new career path for me," says Laura Povlich, 2011-2012 MRS/OSA Congressional Fellow. Povlich was fresh out of her $\mathrm{PhD}$ program and was drawn to the fellowship because she liked the "idea of staying connected to science, but interacting with diverse groups of people on a daily basis." While serving her Congressional Fellowship, Povlich realized she enjoyed the policy aspects but "wanted to work in a job with a more specific scientific emphasis," and applied for an executive branch fellowship, which has turned into a new career as a program officer at the
National Institutes of Health. "I find this broad, interactive, interdisciplinary work to be hugely satisfying since it feeds my desire to constantly learn about new areas of science and promote research when gaps exist," Povlich says.

Andrew Steigerwald, the 2012-2013 MRS/TMS Congressional Fellow, had a similar experience to Povlich, saying that being on "the Hill" gave him "a good sense of how the broader policy ecosystem worked" and his desire to be able to contribute intellectually to the policy conversation around advanced manufacturing led him to serve an executive branch fellowship and transition into a senior advisor position within the Advanced Manufacturing Office of the US Department of Energy (DOE). Serving within the DOE has allowed Steigerwald to "have a more hands-on role in shaping specific, program-level policy," and he characterizes working within the executive branch as "sort of the tip of the spear in terms of deployment of R\&D dollars."

Hurd poses the question, "Where would science funding be without advocacy efforts?" and while he admits that it is hard to quantify, advocacy undoubtedly played a role in the bipartisan support that led to a science-friendly budget for the remainder of fiscal year 2017. With budget decisions looming for 2018, and the administration's proposed budget calling for cuts across the spectrum of STEM agencies, "now is a crucial time for science advocacy," Dozier says. To learn more, reference the links or contact Damon Dozier at Dozier@mrs.org.

Jennifer A. Nekuda Malik 